\title{
Intrinsic and Regulated Gonadotropin-Releasing Hormone Receptor Gene Transcription in Mammalian Pituitary Gonadotrophs
}

\author{
Marija M. Janjic ${ }^{1}$, Stanko S. Stojilkovic ${ }^{2}$ and Ivana Bjelobaba ${ }^{1 *}$ \\ 'Department of Neurobiology, Institute for Biological Research "Sinisa Stankovic", University of Belgrade, Belgrade, Serbia, \\ ${ }^{2}$ Section on Cellular Signaling, Eunice Kennedy Shiver National Institute of Child Health and Human Development, National \\ Institutes of Health, Bethesda, MD, United States
}

OPEN ACCESS

Edited by:

Jacques Epelbaum, Institut national de la santé et de la recherche médicale, France

Reviewed by: Craig Alexander McArdle,

University of Bristol, United Kingdom lain J. Clarke,

Monash University, Australia

*Correspondence:

Ivana Bjelobaba ivana.bjelobaba@ibiss.bg.ac.rs

Specialty section:

This article was submitted to Neuroendocrine Science, a section of the journal Frontiers in Endocrinology

Received: 19 May 2017

Accepted: 16 August 2017 Published: 04 September 2017

Citation:

Janjic MM, Stojilkovic SS and Bjelobaba I (2017) Intrinsic and Regulated Gonadotropin-Releasing

Hormone Receptor Gene

Transcription in Mammalian

Pituitary Gonadotrophs.

Front. Endocrinol. 8:221. doi: 10.3389/fendo.2017.00221
The hypothalamic decapeptide gonadotropin-releasing hormone $(\mathrm{GnRH})$, acting via its receptors (GnRHRs) expressed in pituitary gonadotrophs, represents a critical molecule in control of reproductive functions in all vertebrate species. $\mathrm{GnRH}$-activated receptors regulate synthesis of gonadotropins in a frequency-dependent manner. The number of GnRHRs on the plasma membrane determines the responsiveness of gonadotrophs to $\mathrm{GnRH}$ and varies in relation to age, sex, and physiological status. This is achieved by a complex control that operates at transcriptional, translational, and posttranslational levels. This review aims to overview the mechanisms of GnRHR gene (Gnrhr) transcription in mammalian gonadotrophs. In general, Gnrhr exhibits basal and regulated transcription activities. Basal Gnrhr transcription appears to be an intrinsic property of native and immortalized gonadotrophs that secures the presence of a sufficient number GnRHRs to preserve their functionality independently of the status of regulated transcription. On the other hand, regulated transcription modulates GnRHR expression during development, reproductive cycle, and aging. $\mathrm{GnRH}$ is crucial for regulated Gnrhr transcription in native gonadotrophs but is ineffective in immortalized gonadotrophs. In rat and mouse, both basal and $\mathrm{GnRH}$-induced Gnrhr transcription rely primarily on the protein kinase $\mathrm{C}$ signaling pathway, with subsequent activation of mitogen-activated protein kinases. Continuous $\mathrm{GnRH}$ application, after a transient stimulation, shuts off regulated but not basal transcription, suggesting that different branches of this signaling pathway control transcription. Pituitary adenylate cyclase-activating polypeptide, but not activins, contributes to the regulated transcription utilizing the protein kinase A signaling pathway, whereas a mechanisms by which steroid hormones modulate Gnrhr transcription has not been well characterized.

Keywords: basal transcription, regulated transcription, gonadotrophs, gonadotropin-releasing hormone, gonadotropin-releasing hormone receptor

\section{INTRODUCTION}

The gonadotropin-releasing hormone $(\mathrm{GnRH})$ receptor (GnRHR) is a member of a G proteincoupled receptor family (1). The receptor is expressed in pituitary gonadotrophs of all vertebrates, as well as in other tissues (2). The main signal transduction pathways of activated GnRHR in gonadotrophs is phospholipase C- $\beta 1$-mediated phosphatidylinositol hydrolysis, thereby 
generating inositol-1,4,5-trisphosphate and diacylglycerol (3). Inositol-1,4,5-trisphosphate binds to its receptor at the endoplasmic reticulum membrane, leading to oscillatory $\mathrm{Ca}^{2+}$ release and $\mathrm{Ca}^{2+}$-dependent modulation of electrical activity (4). Diacylglycerol alone or together with $\mathrm{Ca}^{2+}$ activates protein kinase $\mathrm{C}$ (PKC) family of enzymes (5), whereas mitogen-activated protein kinases (MAPK) (6), phospholipase D (7), and phospholipase A2 (8) are PKC downstream signaling proteins. The coupling of GnRHRs to the synthesis of follicle-stimulating hormone (FSH) and synthesis and release of luteinizing hormone $(\mathrm{LH})$ is critical for the establishment of hypothalamic-pituitary-gonadal axis, as these hormones regulate steroidogenesis and gametogenesis. In turn, gonadal hormones exhibit feedback effects at hypothalamic GnRH neurons and pituitary gonadotrophs (6).

The pituitary GnRHR number depends on developmental and reproductive stage and determines their responsiveness to $\mathrm{GnRH}$. The receptor number is regulated, at least in part, at the transcriptional level (9). Cloning of GnRHR cDNA from numerous species facilitated investigations of GnRHR gene (Gnrhr) transcription. In general, transcription of the Gnrhr in gonadotrophs in vitro occurs in the absence (basal) and presence (regulated) of GnRH stimulation (2). The differences in the regulation of Gnrhr expression in mammalian species reflect differences in the promoter region of the gene $(9,10)$. The common aspect of regulated transcription of this gene is up- and downregulation by GnRH, depending on the pattern of application (11-13). Other hormones also contribute to regulation of Gnrhr transcription.

Here, we will mainly discuss Gnrhr transcription in the most frequently used mammalian models: rats, mice, sheep, and immortalized $\alpha \mathrm{T} 3-1$ and L $\beta$ T-2 gonadotrophs. We will first review the literature about in vivo GnRHR mRNA levels during development, aging and reproductive stage, followed by a brief description of rat and mouse Gnrhr structure and promoter region, basal vs. regulated activities, homologous upregulation of gene expression, and effects of gonadal and adrenal steroid hormones and other ligands on transcriptional activity of this gene.

\section{IN VIVO VARIATIONS IN Gnrhr EXPRESSION}

Developmental profile of Gnrhr expression in rats is depicted in Figure 1A. In females, Gnrhr expression increases rapidly over the first 2 weeks of development, followed by a transient decline and secondary rise in 7-8 weeks of age. In males, it increases gradually until 5 weeks of age (14-16), followed by a decline toward a steady expression at the adult age (11). The peak of Gnrhr expression during development correlates well with expression of gonadotropin subunit genes $L h b, F s h b$, and Cga in both sexes (16) as well as with greater $\mathrm{LH}$ and $\mathrm{FSH}$ secretion in females, but not in males
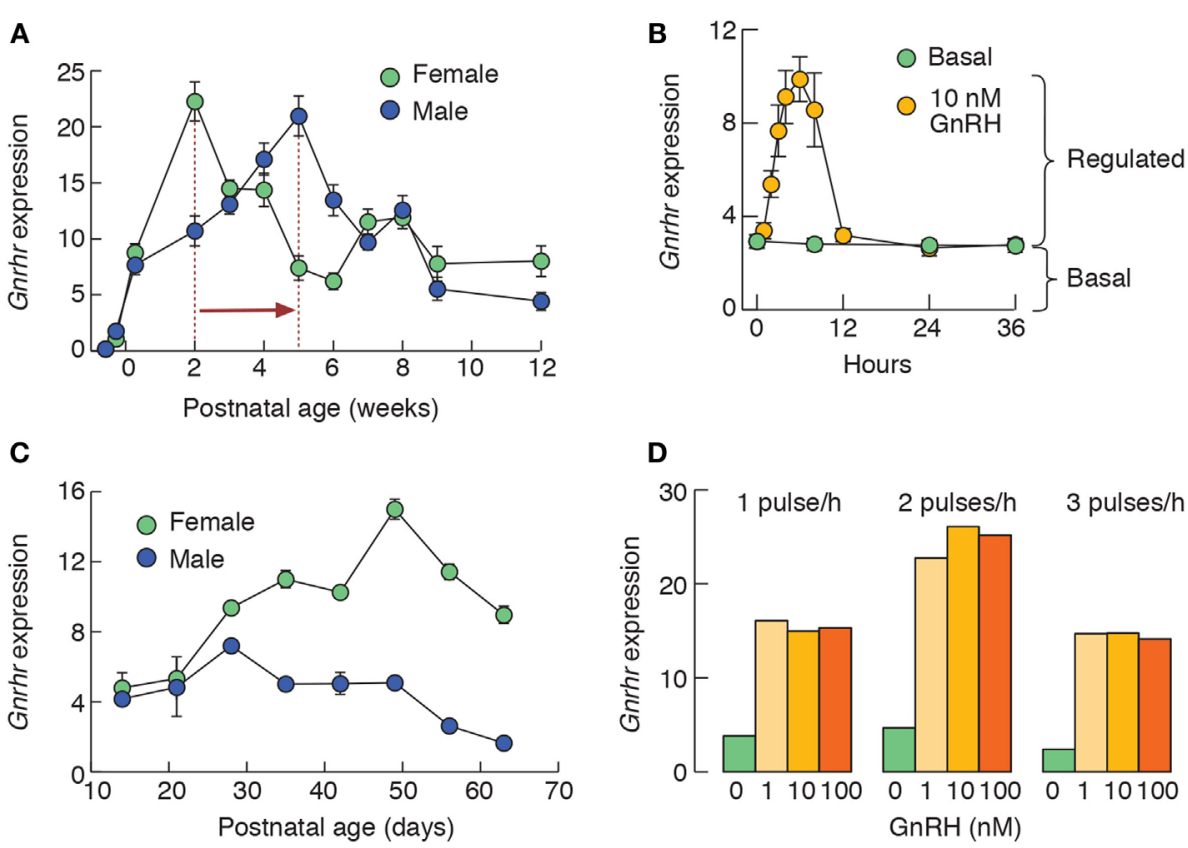

FIGURE 1 | In vivo and in vitro expression patterns of rat pituitary Gnrhr. (A) Female and male developmental profiles of Gnrhr expression in vivo. Notice the differences in the peak of Gnrhr expression in females and males, as indicated by vertical dotted lines and a horizontal arrow. (B) Gonadotropin-releasing hormone $(\mathrm{GnRH})$-induced Gnrhr expression in 2-day-old static cultures of anterior pituitary cells from 7-week-old females. Cells were cultured in the absence or in continuous presence of $10 \mathrm{nM} \mathrm{GnRH}$. Notice that desensitization of $\mathrm{GnRH}$-induced Gnrhr expression does not affect basal expression. (C) The amplitude of GnRH-induced (10 nM continuously for 6 h) Gnrhr expression in female and male pituitary static cultures obtained from animals of different age is sex specific, in contrast to comparable levels of expression of this gene in both sexes in vivo (A). (D) GnRH-induced Gnrhr expression in perifused pituitary cells from rat females. Cells were stimulated with 1,10 , or $100 \mathrm{nM} \mathrm{GnRH}$ for $1 \times 5 \mathrm{~min} /$ hour, $2 \times 5 \mathrm{~min} /$ hour, and $3 \times 5 \mathrm{~min} /$ hour during $6 \mathrm{~h}$. Notice that $1 \mathrm{nM}$ GnRH was sufficient to induce maximum in response. This figure is derived from data published in Ref. $(11,16,20)$; no permission is required from the copyright holder. 
(17). These data are in accordance with the reports on GnRHR concentration and binding capacity during rat ontogeny $(18,19)$.

Gnrhr expression is downregulated in aged male rats (21), probably reflecting impaired $\mathrm{GnRH}$ secretion from the hypothalamus, because pituitary response to $\mathrm{GnRH}$ remains operative (22). However, in middle aged ovariectomized female rats, Gnrhr expression levels were lower than in young ovariectomized animals and the pituitary response to a steroid-induced gonadotropin surge was also impaired (23).

Gnrhr expression in the rat pituitary changes significantly during estrous cycle (24-26). Pituitary GnRHR mRNA content is relatively high on the mornings of diestrus I and diestrus II and declines sharply in the afternoons of diestrus days. However, higher Gnrhr expression can again be observed in the late evening of diestrus II (26). During proestrus, a sharp rise in Gnrhr expression occurs between morning and noon, followed by oscillation in expression until 17:00 h, when a second peak can be observed (25). It should also be noted that maximal binding of D-Ala ${ }^{6}-\mathrm{GnRH}$, a synthetic GnRH analog, occurs at diestrus II as well, indicating that the maximal number of GnRHRs during the cycle is reached before proestrus (27). Estrous is characterized by low Gnrhr expression $(24,25)$. In general, the changes in pituitary Gnrhr levels correlate well with GnRH content and Gnrh expression in the hypothalamus $(25,26)$. In sheep, GnRHR mRNA expression and GnRH binding increase over the luteal phase and decline after the preovulatory LH surge, reaching the lowest levels $24 \mathrm{~h}$ after estrous (28-30).

Ovariectomy in rats and mice reduces the pituitary GnRHR numbers $(31,32)$, combined with marked upregulation of GnRHR mRNA (33). Interestingly, in ovariectomized rats, hypothalamic Gnrh and pituitary Gnrhr expression levels fluctuate during the day (26). In castrated male rats, there was a rise in mRNA, and receptor number, GnRHR affinity for $\mathrm{GnRH}$, and gonadotropin secretion, which was, at least partly, prevented by a testosterone replacement therapy (33-38). Similarly, castration induces upregulation of Gnrhr expression in sheep (39). By contrast, castration was shown to induce a fall in mouse pituitary GnRHR numbers (40).

Rat pituitary responsiveness to $\mathrm{GnRH}$ remains low until 12th day after conception and then rises to reach maximum on the first day postpartum (41). We also noticed lower aplitude of $\mathrm{GnRH}$-induced expression of dentin matrix protein 1 in gonadotrophs from pregnant female rats (20). These data imply that GnRHR mRNA content changes during pregnancy in rat, although this was not investigated. By contrast, pregnancy does not induce changes in GnRHR numbers or mRNA levels in sheep, suggesting that other mechanisms account for a fall in maternal pituitary responsiveness (42). Number of GnRHRs (43-45) as well as Gnrhr expression levels (46) are low during lactation in rat (probably reflecting diminished $\mathrm{GnRH}$ secretion from the hypothalamus), but rise rapidly after pup removal $(45,46)$.

\section{THE STRUCTURE OF Gnrhr PROMOTER REGION}

The $5^{\prime}$-flanking sequences of rat and mouse Gnrhr promoter have been isolated and characterized (47-50). In these species, Gnrhr gene is present as a single copy, positioned on chromosome 14 and 5, respectively, and contains three coding exons and two introns (10). Both promoters share strong homology over the region $1.2 \mathrm{~kb}$ upstream of the ATG codon (50). In this region, two identical response cis-elements of the mouse promoter are present in the rat Gnrhr promoter, a canonical activating protein 1 and steroidogenic factor 1 (also present in the ovine promoter; SF1 or NR5A1) (9). The rat promoter contains two additional response elements that are held responsible for functional differences between rat and mouse promoter: an imperfect cAMP response element, suspected to convey pituitary adenylate cyclase-activating peptide (PACAP) actions, and an element confined to $-252 /-245$, that binds a protein yet unidentified, termed SF1 adjacent protein or SAP. All of these elements are required to mediate the gonadotroph-specific activity (51-53). An element termed the Gnrhr activating sequence, which could confer activin actions in mice, is also present in the rat promoter, but it is inactive (54). Comparing to the mouse promoter, where all known response elements fall in the proximal region, an additional regulatory region containing Gnrhr-specific bipartite enhancer (GnSE) is situated on a more distal part of the rat promoter. Thus, for the full gonadotroph-specific activity of the rat promoter, additional distal elements within the $-1,150 /-750 \mathrm{bp}$ region are required. Two major response elements located at positions $-994 /-960$ and $-871 /-862$ are responsible for GnSE action $(51,52)$. Maximal GnSE activity requires the presence of SF1 response element located in the proximal domain. Both GnSE elements bind LIM-homeodomain proteins LHX3 and ISL1 and this seems to be crucial for gonadotroph-specific expression of the gene $(9,52,55)$. For the detailed structure of rat and mouse promoters, see Ref. (9). The functional properties of the ovine Gnrhr promoter region were not investigated in details; however, the analysis of the $5^{\prime}$-UTR indicates that different mechanisms evolved for pituitary specific expression of Gnrhr in sheep and rodents (56).

\section{BASAL AND GnRH-REGULATED Gnrhr EXPRESSION}

Several lines of evidence indicate that Gnrhr expression is inherent to gonadotrophs. Some functional receptors must be present in gonadotrophs in Kallmann syndrome patients to explain how $\mathrm{GnRH}$ administration restores pituitary and gonadal functions (57). In agreement with this, Gnrhr expression is detectable and functional GnRHRs are present in the rat gonadotrophs in vitro even after prolonged period of GnRH absence (58). Furthermore, prolonged continuous GnRH application does not completely stop Gnrhr transcription (Figure 1B) (11). Finally, naive (never stimulated) $\alpha$ T3-1 and L $\beta$ T-2 cells express functional $\mathrm{Ca}^{2+}$ mobilizing GnRHRs $(59,60)$.

In rat, mouse, and sheep, the main positive regulator of Gnrhr transcription is GnRH itself $(11-13,61)$, depending on the pattern of GnRH application. Figure 1B illustrates that continuous stimulation of rat pituitary cells induces a transient induction of Gnrhr transcription, with maximal response at $6 \mathrm{~h}(11,13)$. Longer GnRH stimulation leads to downregulation in Gnrhr transcription $(11,62)$. Therefore, it is reasonable to postulate that 
pulsatile GnRH stimulation is required not only for gonadotropin subunit expression, but also for the proper regulation of Gnrhr expression $(63,64)$. In the rat pituitary cells, $6 \mathrm{~h}$ application of $\mathrm{GnRH}$ in two pulses per hour, each lasting $5 \mathrm{~min}$, provides the highest amplitude of response (Figure 1D). By contrast, immortalized gonadotrophs do not respond to GnRH application with upregulation in Gnrhr transcription $(11,65)$. This could reflect their embryonic origin or the side-effects of immortalization procedure. However, short GnRH stimulation increases GnRHR binding in $\alpha \mathrm{T} 3-1$ membranes, without apparent effect on Gnrhr expression (66). Continuous GnRH application in $\alpha \mathrm{T} 3-1$ also does not affect GnRHR mRNA levels, but downregulates GnRHR numbers (65). Thus, GnRHR signaling also engages translational regulation. Interestingly, GnRHR signaling induces remodeling of ribosome content in L $\beta$ T-2 cells (67).

We also noticed that basal and GnRH-induced Gnrhr expression depends on the age and sex of rats used for pituitary cell preparation when cells are cultivated in the absence of steroid hormones. Although the relationship between basal and GnRHstimulated transcriptional activity is comparable in both sexes, the amplitude of response to $\mathrm{GnRH}$ increases in female from juvenile to adult stage, but this is not the case with male rat cells (Figure 1C) (11). It is interesting to speculate that epigenetic modifications may have a role in the observed differences, although Gnrhr promoter regions in mouse and rat are not rich in cytosine-phosphate-guanine islands (68).

Gonadotropin-releasing hormone-induced Gnrhr expression relies, at least partially, on PKC activation and subsequent MAPK phosphorylation. The localization of the GnRHR in the lipid rafts (69) is important for activation of these signaling pathways $(70,71)$. The roles of different PKC isoforms in activation of the "classical" MAPK signaling pathways, composed of extracellular signal-regulated kinase (ERK1/2 and ERK5), c-Jun N-terminal kinases (JNK1/2) and p38, were characterized in immortalized gonadotrophs (72-75), but not in native gonadotrophs. MAPKs activate Fos and Jun proteins, which form a complex that binds to the AP1 site. GnRH itself also induces Fos, Jun, and Junb transcription in the rat gonadotrophs $(20,76)$. GnRH-induced Gnrhr expression in dispersed rat pituitary cells seems to depend mostly on ERK1/2 pathway, with a small but significant involvement of p38 and ERK5 (11). Intriguingly, although JNK1/2 was shown to play a critical role in GnRH induction of the Gnrhr expression in $\alpha$ T3-1 cells (77), inhibition of JNK1/2 had no effect on basal or GnRH-stimulated Gnrhr expression in the primary cultures (11). Whether this means that, in the rat gonadotrophs, Jun proteins are activated trough alternative pathways or that they are already active in a manner sufficient to induce transcription, remains to be elucidated.

Basal Gnrhr transcription also depends on PKC-MAPK signaling pathway (11). However, the existence of basal Gnrhr expression during continuous $\mathrm{GnRH}$ application could be explained by the fact that the signaling pathways downstream of PKC may also be activated by other factors, whose signaling converges to MAPKs. Indeed, increased $\mathrm{Ca}^{2+}$ influx, which in gonadotrophs is also stimulated by PKC (78), is sufficient to induce Gnrhr transcription (11), which may imply the possible role of calmodulin in activation of MAPKs (79). Also, portions of ERK1/2 and p38 are phosphorylated and therefore active under basal conditions in immortalized gonadotrophs $(74,80)$. Although infertile, female ERK1/2 knockout mice also retain Gnrhr expression in the pituitary (81), indicating that basal Gnrhr expression only partially relies on this pathway, at least in the mouse. Accordingly, cFos-deficient mice show an aberrant, but not completely abolished Gnrhr expression (82). In addition, in the rat pituitary cells, ERK inhibition cannot eliminate GnRH-induced Gnrhr transcription completely (11).

\section{DEPENDENCE OF Gnrhr EXPRESSION ON PACAP AND ACTIVINS}

Pituitary adenylate cyclase-activating peptide from hypothalamus may reach the pituitary, but could also be synthetized in the pituitary by gonadotrophs and folliculostellate cells (83), i.e., it could act as an autocrine/paracrine regulator of gonadotrophs by activating its PAC1 receptor expressed in these cells (84). Like GnRH, PACAP activates $\mathrm{Ca}^{2+}$ release in inositol-1,4,5trisphosphate-depedent manner (85), but also increases cAMP production, leading to an activation of protein kinase A (86). A high pulse frequency PACAP administration to L $\beta$ T-2 cells induced Gnrhr transcription (87) and in $\alpha \mathrm{T} 3-1$ cells with a rat Gnrhr construct, dibutyryl-cAMP increased promoter activity (49). On the other hand, PKA stimulation by forskolin failed to induce Gnrhr transcription in L $\beta \mathrm{T}-2$ cells (11). Although a bipartite element in the rat Gnrhr promoter was identified and termed as PACAP response elements I and II (53), the role of PACAP in regulation of Gnrhr expression in rat, mouse, and sheep gonadotrophs should be further investigated.

Activin-A stimulates GnRHR synthesis in pituitary cells from juvenile female rats. This effect could not be abolished by inhibin (88) and probably is posttranscriptional; unlike mouse, rat promoter region does not contain a functional activin response element (10). Although activin A, alone or in synergy with $\mathrm{GnRH}$ was shown to influence Gnrhr transcription upregulation in $\alpha$ T3-1 cells $(89,90)$, activin receptor II is not required for Gnrhr expression in mice (91). For more details on in vitro and in vivo actions of activins, see Ref. (92).

Prolonged inhibin treatment of the rat pituitary cells cuts the number of GnRHR in half (93), while in ovine pituitary cell culture, $48 \mathrm{~h}$ inhibin treatment increases GnRHR binding (94). Continuous microinfusion of inhibin downregulates GnRHR mRNA levels in immature male rats, but this effect could not be observed in adult animals (15).

\section{DEPENDENCE OF Gnrhr TRANSCRIPTION ON STEROID HORMONES}

In intact rats and sheep, serum estradiol correlates well with increased GnRHR numbers $(27,95)$, suggesting stimulatory effect of this steroid on transcriptional and/or posttranscriptional events. In contrast to estradiol, progesterone suppresses Gnrhr transcription and downregulates pituitary responsiveness to GnRH in mammals $(94,96-98)$. Progesterone treatment also reduces GnRHR mRNA levels after LH surge in estradiol primed 
TABLE 1 | Up- and downregulation of Gnrhr expression by hypothalamic, intrapituitary, gonadal, adrenal hormones, and factors.

\begin{tabular}{|c|c|c|c|}
\hline & Upregulation & Downregulation & No effect \\
\hline Rats in vivo & $\mathrm{GnRH}, \mathrm{E} 2$ (122) & P (96), Cetrorelix (123), Inhibin (15) & \\
\hline Rat pituitary cells & $\mathrm{GnRH}(11,20)$ & & E2, P (108) \\
\hline Mouse pituitary cells & $\mathrm{GnRH}(11)$ & & \\
\hline Mouse $L \beta T-2$ cells & Dexamethasone (111, 119), PACAP (87), Activin-A (119) & & GnRH (11), E2 (111) \\
\hline Mouse $\alpha \mathrm{T} 3-1$ cells & GnRH (77), Triptorelin (110), Dibutyryl-cAMP (49), Activin-A (89) & E2, $P(110)$ & $\mathrm{GnRH}(65)$ \\
\hline Sheep in vivo & $\mathrm{GnRH}(61), \mathrm{E} 2(62,116,124)$ & $P(98)$ & Cortisol $(115,116)$ \\
\hline Ovine pituitary cells & E2 (106) & & \\
\hline
\end{tabular}

ovariectomized female rats (96). Furthermore, it was suggested that a decrease in progesterone, rather than an increase in estradiol, during luteolysis is responsible for the increase in GnRHR mRNA and GnRHR number in the ovine pituitary (99-101). In male rats, there was a negative correlation between GnRHR-binding capacity and testosterone levels in serum $(18,19)$, further suggesting that androgen treatment also inhibits Gnrhr transcription/posttranscriptional events. However, these in vivo experiments could not dissociate between the direct effects of gonadal steroid hormones on Gnrhr transcription from the indirect effects mediated by modulation of $\mathrm{GnRH}$ secretory pattern. Gonadotrophs from castrated rats showed fewer $\mathrm{GnRH}$-induced spike-plateau $\mathrm{Ca}^{2+}$ responses than cells obtained from intact rats (102), which could be reversed by treatment with a testosterone analog, thus implying its direct effect $(102,103)$.

The estradiol regulation of the GnRHR numbers in sheep was extensively studied [for review, see Ref. (104)]. In vivo administration of estradiol in orchidectomized sheep increased GnRHR mRNA content (105). Similarly, in ovine pituitary cultures, prolonged estradiol treatment increased the number of GnRHRs (106) and Gnrhr expression, which was greatly attenuated by progesterone $(94,107)$. Addition of progesterone alone also reduced GnRHR binding (94). By contrast, neither estradiol nor progesterone affect basal Gnrhr expression in the female rat pituitary cells, while progesterone inhibits GnRH-induced Gnrhr expression (108). In $\alpha$ T3-1 cells, estradiol reduced GnRHR numbers and mRNA $(109,110)$, but did not affect Gnrhr expression in L $\beta$ T-2 cells (111).

However, an estradiol responsive element is not present within rat or mouse and ovine Gnrhr promoter $(9,10,56)$ and rat Gnrhr promoter region does not contain the progesterone binding element $(9,10)$. It was suggested that estradiol effect on Gnrhr transcription occurs through membrane associated estrogen receptor- $\alpha$ (112), while mechanism(s) of progesterone action remain unclear.

It is well established that adrenal glucocorticoids affect reproduction (113), but the role of endogenous glucocorticoids in the regulation of Gnrhr expression in rats and mice has not been systematically investigated (114). However, continuous infusion of cortisol did not change Gnrhr expression in orchidectomized sheep, although it reduced the amplitude of estradiol-induced Gnrhr expression upregulation $(115,116)$. Studies in rats showed that corticosterone and cortisol do not have an effect on GnRHR numbers $(117,118)$. Dexametasone stimulated Gnrhr expression in L $\beta$ T-2 cells $(111,119)$. In mouse Gnrhr promoter, an activating protein 1 containing site was identified as a mediator of dexamethasone induced transcription $(120,121)$.

\section{CONCLUSION}

Gnrhr transcription is a functional marker of differentiated gonadotrophs. It occurs in the absence of any stimuli and is regulated by several hormones (Table 1 ). The main regulator of transcription of this gene is hypothalamic GnRH and pulsatile $\mathrm{GnRH}$ exposure is needed to sustain this process. Transcription is also facilitated by PACAP in an autocrine/paracrine manner, while activins are unlikely to play a physiological role in Gnrhr transcription. Steroid hormones influence Gnrhr transcription through regulation of $\mathrm{GnRH}$ secretion and directly, through a largely uncharacterized mechanisms. The mouse immortalized $\alpha \mathrm{T} 3-1$ and L $\beta$ T- 2 cells remain, to this day, the best characterized gonadotroph cell model, although data obtained using these cells do not always correlate with findings in primary mouse and rat pituitary cells. Further studies are needed to elucidate signaling pathways accounting for control of Gnrhr transcription, especially in sheep. This includes the possible effects of gonadectomy or steroid hormone application on MAPK signaling.

\section{AUTHOR CONTRIBUTIONS}

All authors (MJ, SS, and IB) contributed to the writing of the manuscript.

\section{FUNDING}

This work was supported by the Ministry of Education, Science and Technological Development of the Republic of Serbia, Grant III 41014 (MJ and IB), and by the Intramural Research Program of the National Institute of Child Health and Human Development, NIH, Project ZIA HD 000195-22 (SS). 


\section{REFERENCES}

1. Millar RP, Lu ZL, Pawson AJ, Flanagan CA, Morgan K, Maudsley SR. Gonadotropin-releasing hormone receptors. Endocr Rev (2004) 25:235-75. doi:10.1210/er.2003-0002

2. McArdle CA, Roberson MS. Chapter 10 - gonadotropes and gonadotropin-releasing hormone signaling. Fourth ed. In: Plant TM, Zeleznik AJ, editors. Knobil and Neill's Physiology of Reproduction. San Diego: Academic Press (2015). p. 335-97.

3. Naor Z, Huhtaniemi I. Interactions of the GnRH receptor with heterotrimeric G proteins. Front Neuroendocrinol (2013) 34:88-94. doi:10.1016/j. yfrne.2012.11.001

4. Stojilkovic SS, Tabak J, Bertram R. Ion channels and signaling in the pituitary gland. Endocr Rev (2010) 31:845-915. doi:10.1210/er.2010-0005

5. Naor Z, Harris D, Shacham S. Mechanism of GnRH receptor signaling: combinatorial cross-talk of $\mathrm{Ca}^{2+}$ and protein kinase C. Front Neuroendocrinol (1998) 19:1-19. doi:10.1006/frne.1997.0162

6. Bliss SP, Navratil AM, Xie J, Roberson MS. GnRH signaling, the gonadotrope and endocrine control of fertility. Front Neuroendocrinol (2010) 31:322-40. doi:10.1016/j.yfrne.2010.04.002

7. Stojilkovic SS, Catt KJ. Novel aspects of GnRH-induced intracellular signaling and secretion in pituitary gonadotrophs. J Neuroendocrinol (1995) 7:739-57. doi:10.1111/j.1365-2826.1995.tb00711.x

8. Naor Z. Signaling by G-protein-coupled receptor (GPCR): studies on the GnRH receptor. Front Neuroendocrinol (2009) 30:10-29. doi:10.1016/j. yfrne.2008.07.001

9. Schang AL, Querat B, Simon V, Garrel G, Bleux C, Counis R, et al. Mechanisms underlying the tissue-specific and regulated activity of the Gnrhr promoter in mammals. Front Endocrinol (2012) 3:162. doi:10.3389/fendo.2012.00162

10. Hapgood JP, Sadie H, van Biljon W, Ronacher K. Regulation of expression of mammalian gonadotrophin-releasing hormone receptor genes. J Neuroendocrinol (2005) 17:619-38. doi:10.1111/j.1365-2826.2005. 01353.x

11. Bjelobaba I, Janjic MM, Tavcar JS, Kucka M, Tomic M, Stojilkovic SS. The relationship between basal and regulated Gnrhr expression in rodent pituitary gonadotrophs. Mol Cell Endocrinol (2016) 437:302-11. doi:10.1016/j. mce.2016.08.040

12. Cheon M, Park D, Park Y, Kam K, Park SD, Ryu K. Homologous upregulation of gonadotropin-releasing hormone receptor mRNA occurs through transcriptional activation rather than modulation of mRNA stability. Endocrine (2000) 13:47-53. doi:10.1385/ENDO:13:1:47

13. Cheon M, Park D, Kim K, Park SD, Ryu K. Homologous upregulation of $\mathrm{GnRH}$ receptor mRNA by continuous $\mathrm{GnRH}$ in cultured rat pituitary cells. Endocrine (1999) 11:49-55. doi:10.1385/ENDO:11:1:49

14. Wilson ME, Handa RJ. Ontogeny of gene expression in the gonadotroph of the developing female rat. Biol Reprod (1997) 56:563-8. doi:10.1095/ biolreprod56.2.563

15. Winters SJ, Pohl CR, Adedoyin A, Marshall GR. Effects of continuous inhibin administration on gonadotropin secretion and subunit gene expression in immature and adult male rats. Biol Reprod (1996) 55:1377-82. doi:10.1095/ biolreprod55.6.1377

16. Bjelobaba I, Janjic MM, Kucka M, Stojilkovic SS. Cell type-specific sexual dimorphism in rat pituitary gene expression during maturation. Biol Reprod (2015) 93:21. doi:10.1095/biolreprod.115.129320

17. Dohler KD, Wuttke W. Serum LH, FSH, prolactin and progesterone from birth to puberty in female and male rats. Endocrinology (1974) 94:1003-8. doi:10.1210/endo-94-4-1003

18. Chan V, Clayton RN, Knox G, Catt KJ. Ontogeny of pituitary GnRH receptors in the rat. Endocrinology (1981) 108:2086-92. doi:10.1210/endo-108-6-2086

19. Dalkin AC, Bourne GA, Pieper DR, Regiani S, Marshall JC. Pituitary and gonadal gonadotropin-releasing hormone receptors during sexual maturation in the rat. Endocrinology (1981) 108:1658-64. doi:10.1210/endo-1085-1658

20. Kucka M, Bjelobaba I, Clokie SJ, Klein DC, Stojilkovic SS. Female-specific induction of rat pituitary dentin matrix protein-1 by GnRH. Mol Endocrinol (2013) 27:1840-55. doi:10.1210/me.2013-1068

21. Chen H. Gene expression by the anterior pituitary gland: effects of age and caloric restriction. Mol Cell Endocrinol (2004) 222:21-31. doi:10.1016/j. mce.2004.05.004
22. Gruenewald DA, Naai MA, Marck BT, Matsumoto AM. Age-related decrease in hypothalamic gonadotropin-releasing hormone $(\mathrm{GnRH})$ gene expression, but not pituitary responsiveness to $\mathrm{GnRH}$, in the male Brown Norway rat. J Androl (2000) 21:72-84.

23. Zheng W, Jimenez-Linan M, Rubin BS, Halvorson LM. Anterior pituitary gene expression with reproductive aging in the female rat. Biol Reprod (2007) 76:1091-102. doi:10.1095/biolreprod.106.057877

24. Kakar SS, Grantham K, Musgrove LC, Devor D, Sellers JC, Neill JD. Rat gonadotropin-releasing hormone $(\mathrm{GnRH})$ receptor: tissue expression and hormonal regulation of its mRNA. Mol Cell Endocrinol (1994) 101:151-7. doi:10.1016/0303-7207(94)90229-1

25. Schirman-Hildesheim TD, Bar T, Ben-Aroya N, Koch Y. Differential gonadotropin-releasing hormone $(\mathrm{GnRH})$ and $\mathrm{GnRH}$ receptor messenger ribonucleic acid expression patterns in different tissues of the female rat across the estrous cycle. Endocrinology (2005) 146:3401-8. doi:10.1210/en. 2005-0240

26. Schirman-Hildesheim TD, Ben-Aroya N, Koch Y. Daily GnRH and GnRHreceptor mRNA expression in the ovariectomized and intact rat. Mol Cell Endocrinol (2006) 252:120-5. doi:10.1016/j.mce.2006.03.010

27. Savoy-Moore RT, Schwartz NB, Duncan JA, Marshall JC. Pituitary gonadotropin-releasing hormone receptors during the rat estrous cycle. Science (1980) 209:942-4. doi:10.1126/science.6250218

28. Padmanabhan V, Dalkin A, Yasin M, Haisenleder DJ, Marshall JC, Landefeld TD. Are immediate early genes involved in gonadotropin-releasing hormone receptor gene regulation? Characterization of changes in $\mathrm{GnRH}$ receptor (GnRH-R), c-fos, and c-jun messenger ribonucleic acids during the ovine estrous cycle. Biol Reprod (1995) 53:263-9. doi:10.1095/ biolreprod53.2.263

29. Brooks J, Taylor PL, Saunders PT, Eidne KA, Struthers WJ, McNeilly AS. Cloning and sequencing of the sheep pituitary gonadotropin-releasing hormone receptor and changes in expression of its mRNA during the estrous cycle. Mol Cell Endocrinol (1993) 94:R23-7. doi:10.1016/0303-7207(93) 90177-L

30. Ciechanowska M, Lapot M, Mateusiak K, Przekop F. Neuroendocrine regulation of $\mathrm{GnRH}$ release and expression of $\mathrm{GnRH}$ and $\mathrm{GnRH}$ receptor genes in the hypothalamus-pituitary unit in different physiological states. Reprod Biol (2010) 10:85-124. doi:10.1016/S1642-431X(12)60054-0

31. Belisle S, Bellabarba D, Lehoux JG. Basal and stimulated LHRH receptor sites in the pituitary of aging female mice. Gynecol Endocrinol (1989) 3:183-92. doi:10.3109/09513598909152299

32. Naik SI, Young LS, Charlton HM, Clayton RN. Pituitary gonadotropin-releasing hormone receptor regulation in mice. II: Females. Endocrinology (1984) 115:114-20. doi:10.1210/endo-115-1-114

33. Kaiser UB, Jakubowiak A, Steinberger A, Chin WW. Regulation of rat pituitary gonadotropin-releasing hormone receptor mRNA levels in vivo and in vitro. Endocrinology (1993) 133:931-4. doi:10.1210/endo.133.2. 8393779

34. Wilson CA, Herdon HJ, Bailey LC, Clayton RN. Effect of testosterone on gonadotrophin-releasing hormone receptors in the castrated rat: preliminary evidence for a stimulatory effect of testosterone on gonadotrophin function in the male rat. J Endocrinol (1986) 108:441-9. doi:10.1677/joe.0. 1080441

35. Frager MS, Pieper DR, Tonetta SA, Duncan JA, Marshall JC. Pituitary gonadotropin-releasing hormone receptors. Effects of castration, steroid replacement, and the role of gonadotropin-releasing hormone in modulating receptors in the rat. J Clin Invest (1981) 67:615-23. doi:10.1172/JCI110075

36. Conne BS, Scaglioni S, Lang U, Sizonenko PC, Aubert ML. Pituitary receptor sites for gonadotropin-releasing hormone: effect of castration and substitutive therapy with sex steroids in the male rat. Endocrinology (1982) 110:70-9. doi:10.1210/endo-110-1-70

37. Garcia A, Schiff M, Marshall JC. Regulation of pituitary gonadotropin-releasing hormone receptors by pulsatile gonadotropin-releasing hormone injections in male rats. Modulation by testosterone. J Clin Invest (1984) 74:920-8. doi:10.1172/JCI111510

38. Clayton RN, Catt KJ. Regulation of pituitary gonadotropin-releasing hormone receptors by gonadal hormones. Endocrinology (1981) 108:887-95. doi:10.1210/endo-108-3-887

39. Illing N, Jacobs GF, Becker II, Flanagan CA, Davidson JS, Eales A, et al. Comparative sequence analysis and functional characterization of the cloned 
sheep gonadotropin-releasing hormone receptor reveal differences in primary structure and ligand specificity among mammalian receptors. Biochem Biophys Res Commun (1993) 196:745-51. doi:10.1006/bbrc.1993.2312

40. Naik SI, Young LS, Charlton HM, Clayton RN. Pituitary gonadotropinreleasing hormone receptor regulation in mice. I: Males. Endocrinology (1984) 115:106-13.

41. Koiter TR, van der Schaaf-Verdonk GC, Schuiling GA. Pituitary responsiveness to LHRH during pregnancy in the rat: effect of progesterone. J Endocrinol (1987) 115:247-54. doi:10.1677/joe.0.1150247

42. Fowler PA, McNeilly AS. Maternal pituitary gonadotroph function in relation to $\mathrm{GnRH}$ receptor and LH beta mRNA content during pregnancy in ewes. J Reprod Fertil (1997) 110:267-78. doi:10.1530/jrf.0.1100267

43. Marian J, Cooper RL, Conn PM. Regulation of the rat pituitary gonadotropin-releasing hormone receptor. Mol Pharmacol (1981) 19:399-405.

44. Smith MS. Effects of the intensity of the suckling stimulus and ovarian steroids on pituitary gonadotropin-releasing hormone receptors during lactation. Biol Reprod (1984) 31:548-55. doi:10.1095/biolreprod31.3.548

45. Smith MS, Lee LR. Modulation of pituitary gonadotropin-releasing hormone receptors during lactation in the rat. Endocrinology (1989) 124:1456-61. doi:10.1210/endo-124-3-1456

46. Smith MS, Reinhart J. Changes in pituitary gonadotropin-releasing hormone receptor messenger ribonucleic acid content during lactation and after pup removal. Endocrinology (1993) 133:2080-4. doi:10.1210/endo.133.5. 8404656

47. Albarracin CT, Kaiser UB, Chin WW. Isolation and characterization of the 5'-flanking region of the mouse gonadotropin-releasing hormone receptor gene. Endocrinology (1994) 135:2300-6. doi:10.1210/endo.135.6. 7988412

48. Clay CM, Nelson SE, Digregorio GB, Campion CE, Wiedemann AL, Nett RJ. Cell-specific expression of the mouse gonadotropin-releasing hormone $(\mathrm{GnRH})$ receptor gene is conferred by elements residing within 500 bp of proximal 5' flanking region. Endocrine (1995) 3:615-22. doi:10.1007/ BF02953028

49. Reinhart J, Xiao S, Arora KK, Catt KJ. Structural organization and characterization of the promoter region of the rat gonadotropin-releasing hormone receptor gene. Mol Cell Endocrinol (1997) 130:1-12. doi:10.1016/ S0303-7207(97)00064-6

50. Pincas H, Forrai Z, Chauvin S, Laverriere JN, Counis R. Multiple elements in the distal part of the $1.2 \mathrm{~kb} 5$ '-flanking region of the rat $\mathrm{GnRH}$ receptor gene regulate gonadotrope-specific expression conferred by proximal domain. Mol Cell Endocrinol (1998) 144:95-108. doi:10.1016/S0303-7207(98) 00149-X

51. Pincas H, Amoyel K, Counis R, Laverriere JN. Proximal cis-acting elements, including steroidogenic factor 1 , mediate the efficiency of a distal enhancer in the promoter of the rat gonadotropin-releasing hormone receptor gene. Mol Endocrinol (2001) 15:319-37. doi:10.1210/mend.15.2.0593

52. Granger A, Bleux C, Kottler ML, Rhodes SJ, Counis R, Laverriere JN. The LIM-homeodomain proteins Isl- 1 and Lhx3 act with steroidogenic factor 1 to enhance gonadotrope-specific activity of the gonadotropin-releasing hormone receptor gene promoter. Mol Endocrinol (2006) 20:2093-108. doi:10.1210/me.2005-0184

53. Pincas $\mathrm{H}$, Laverriere JN, Counis R. Pituitary adenylate cyclase-activating polypeptide and cyclic adenosine 3,5'-monophosphate stimulate the promoter activity of the rat gonadotropin-releasing hormone receptor gene via a bipartite response element in gonadotrope-derived cells. J Biol Chem (2001) 276:23562-71. doi:10.1074/jbc.M100563200

54. Cherrington BD, Farmerie TA, Lents CA, Cantlon JD, Roberson MS, Clay CM. Activin responsiveness of the murine gonadotropin-releasing hormone receptor gene is mediated by a composite enhancer containing spatially distinct regulatory elements. Mol Endocrinol (2005) 19:898-912. doi:10.1210/me.2004-0214

55. Schang AL, Granger A, Querat B, Bleux C, Cohen-Tannoudji J, Laverriere JN. GATA2-induced silencing and LIM-homeodomain protein-induced activation are mediated by a bi-functional response element in the rat GnRH receptor gene. Mol Endocrinol (2013) 27:74-91. doi:10.1210/ me.2012-1182

56. Campion CE, Turzillo AM, Clay CM. The gene encoding the ovine gonadotropin-releasing hormone $(\mathrm{GnRH})$ receptor: cloning and initial characterization. Gene (1996) 170:277-80. doi:10.1016/0378-1119(96)00042-X
57. Chryssikopoulos A, Gregoriou O, Vitoratos N, Rizos D, Papadias K. The predictive value of double Gn-RH provocation test in unprimed Gn-RHprimed and steroid-primed female patients with Kallmann's syndrome. Int J Fertil Womens Med (1998) 43:291-9.

58. Tomic M, Cesnajaj M, Catt KJ, Stojilkovic SS. Developmental and physiological aspects of $\mathrm{Ca}^{2+}$ signaling in agonist-stimulated pituitary gonadotrophs. Endocrinology (1994) 135:1762-71. doi:10.1210/endo.135.5.7956899

59. Merelli F, Stojilkovic SS, Iida T, Krsmanovic LZ, Zheng L, Mellon PL, et al. Gonadotropin-releasing hormone-induced calcium signaling in clonal pituitary gonadotrophs. Endocrinology (1992) 131:925-32. doi:10.1210/ endo.131.2.1379169

60. Naidich M, Shterntal B, Furman R, Pawson AJ, Jabbour HN, Morgan K, et al. Elucidation of mechanisms of the reciprocal cross talk between gonadotropinreleasing hormone and prostaglandin receptors. Endocrinology (2010) 151:2700-12. doi:10.1210/en.2009-1335

61. Turzillo AM, Juengel JL, Nett TM. Pulsatile gonadotropin-releasing hormone $(\mathrm{GnRH})$ increases concentrations of GnRH receptor messenger ribonucleic acid and numbers of GnRH receptors during luteolysis in the ewe. Biol Reprod (1995) 53:418-23. doi:10.1095/biolreprod53.2.418

62. Turzillo AM, Nolan TE, Nett TM. Regulation of gonadotropin-releasing hormone $(\mathrm{GnRH})$ receptor gene expression in sheep: interaction of $\mathrm{GnRH}$ and estradiol. Endocrinology (1998) 139:4890-4. doi:10.1210/endo.139.12. 6344

63. Ferris HA, Shupnik MA. Mechanisms for pulsatile regulation of the gonadotropin subunit genes by GNRH1. Biol Reprod (2006) 74:993-8. doi:10.1095/ biolreprod.105.049049

64. Kaiser UB, Jakubowiak A, Steinberger A, Chin WW. Differential effects of gonadotropin-releasing hormone $(\mathrm{GnRH})$ pulse frequency on gonadotropin subunit and GnRH receptor messenger ribonucleic acid levels in vitro. Endocrinology (1997) 138:1224-31. doi:10.1210/endo.138.3.4968

65. Tsutsumi M, Laws SC, Rodic V, Sealfon SC. Translational regulation of the gonadotropin-releasing hormone receptor in alpha T3-1 cells. Endocrinology (1995) 136:1128-36. doi:10.1210/endo.136.3.7867566

66. Tsutsumi M, Laws SC, Sealfon SC. Homologous up-regulation of the gonadotropin-releasing hormone receptor in alpha T3-1 cells is associated with unchanged receptor messenger RNA (mRNA) levels and altered mRNA activity. Mol Endocrinol (1993) 7:1625-33. doi:10.1210/me.7.12.1625

67. Do M-HT, Kim T, He F, Dave H, Intriago RE, Astorga UA, et al. Polyribosome and ribonucleoprotein complex redistribution of mRNA induced by GnRH involves both EIF2AK3 and MAPK signaling. Mol Cell Endocrinol (2014) 382:346-57. doi:10.1016/j.mce.2013.10.007

68. Laverriere JN, L'Hote D, Tabouy L, Schang AL, Querat B, CohenTannoudji J. Epigenetic regulation of alternative promoters and enhancers in progenitor, immature, and mature gonadotrope cell lines. Mol Cell Endocrinol (2016) 434:250-65. doi:10.1016/j.mce.2016.07.010

69. Navratil AM, Farmerie TA, Bogerd J, Nett TM, Clay CM. Differential impact of intracellular carboxyl terminal domains on lipid raft localization of the murine gonadotropin-releasing hormone receptor. Biol Reprod (2006) 74:788-97. doi:10.1095/biolreprod.105.048157

70. Bliss SP, Navratil AM, Breed M, Skinner DC, Clay CM, Roberson MS. Signaling complexes associated with the type I gonadotropin-releasing hormone $(\mathrm{GnRH})$ receptor: colocalization of extracellularly regulated kinase 2 and GnRH receptor within membrane rafts. Mol Endocrinol (2007) 21:538-49. doi:10.1210/me.2006-0289

71. Allen-Worthington K, Xie J, Brown JL, Edmunson AM, Dowling A, Navratil AM, et al. The F0F1 ATP synthase complex localizes to membrane rafts in gonadotrope cells. Mol Endocrinol (2016) 30:996-1011. doi:10.1210/ me.2015-1324

72. Dobkin-Bekman M, Rahamin-Ben Navi L, Shterntal B, Sviridonov L, Przedecki F, Naidich-Exler M, et al. Differential role of PKC isoforms in GnRH and phorbol 12-myristate 13-acetate activation of extracellular signal-regulated kinase and Jun N-terminal kinase. Endocrinology (2010) 151:4894-907. doi:10.1210/en.2010-0114

73. Mugami S, Dobkin-Bekman M, Rahamim-Ben Navi L, Naor Z. Differential roles of PKC isoforms (PKCs) in GnRH stimulation of MAPK phosphorylation in gonadotrope derived cells. Mol Cell Endocrinol (2017). doi:10.1016/j. mce.2017.04.004

74. Mugami S, Kravchook S, Rahamim-Ben Navi L, Seger R, Naor Z. Differential roles of PKC isoforms (PKCs) and $\mathrm{Ca}^{2+}$ in $\mathrm{GnRH}$ and phorbol 12-myristate 
13-acetate (PMA) stimulation of p38MAPK phosphorylation in immortalized gonadotrope cells. Mol Cell Endocrinol (2017) 439:141-54. doi:10.1016/j. mce.2016.10.031

75. Rahamim-Ben Navi L, Tsukerman A, Feldman A, Melamed P, Tomic M, Stojilkovic SS, et al. GnRH induces ERK-dependent bleb formation in gonadotrope cells, involving recruitment of members of a GnRH receptorassociated signalosome to the Blebs. Front Endocrinol (2017) 8:113. doi:10.3389/fendo.2017.00113

76. Cesnjaj M, Catt KJ, Stojilkovic SS. Coordinate actions of calcium and protein kinase-C in the expression of primary response genes in pituitary gonadotrophs. Endocrinology (1994) 135:692-701. doi:10.1210/endo.135.2. 7518388

77. Ellsworth BS, White BR, Burns AT, Cherrington BD, Otis AM, Clay CM. c-Jun N-terminal kinase activation of activator protein-1 underlies homologous regulation of the gonadotropin-releasing hormone receptor gene in alpha T3-1 cells. Endocrinology (2003) 144:839-49. doi:10.1210/en.2002220784

78. Stojilkovic SS, Iida T, Merelli F, Torsello A, Krsmanovic LZ, Catt KJ. Interactions between calcium and protein kinase $\mathrm{C}$ in the control of signaling and secretion in pituitary gonadotrophs. J Biol Chem (1991) 266:10377-84.

79. Roberson MS, Bliss SP, Xie J, Navratil AM, Farmerie TA, Wolfe MW, et al. Gonadotropin-releasing hormone induction of extracellular-signal regulated kinase is blocked by inhibition of calmodulin. Mol Endocrinol (2005) 19:2412-23. doi:10.1210/me.2005-0094

80. Bar-Lev TH, Harris D, Tomic M, Stojilkovic S, Blumenfeld Z, Brown P, et al. Role of PI4K and PI3K-AKT in ERK1/2 activation by GnRH in the pituitary gonadotropes. Mol Cell Endocrinol (2015) 415:12-23. doi:10.1016/j. mce.2015.07.029

81. Bliss SP, Miller A, Navratil AM, Xie J, McDonough SP, Fisher PJ, et al. ERK signaling in the pituitary is required for female but not male fertility. $\mathrm{Mol}$ Endocrinol (2009) 23:1092-101. doi:10.1210/me.2009-0030

82. Xie C, Jonak CR, Kauffman AS, Coss D. Gonadotropin and kisspeptin gene expression, but not GnRH, are impaired in cFOS deficient mice. Mol Cell Endocrinol (2015) 411:223-31. doi:10.1016/j.mce.2015.04.033

83. Winters SJ, Moore JP Jr. PACAP, an autocrine/paracrine regulator of gonadotrophs. Biol Reprod (2011) 84:844-50. doi:10.1095/biolreprod.110. 087593

84. Purwana IN, Kanasaki H, Oride A, Mijiddorj T, Miyazaki K. Expression of the pituitary adenylate cyclase-activating polypeptide (PACAP) type 1 receptor (PAC1R) potentiates the effects of GnRH on gonadotropin subunit gene expression. Biochem Biophys Res Commun (2011) 410:295-300. doi:10.1016/j.bbrc.2011.05.135

85. Rawlings SR, Demaurex N, Schlegel W. Pituitary adenylate cyclase-activating polypeptide increases [Ca2]i in rat gonadotrophs through an inositol trisphosphate-dependent mechanism. J Biol Chem (1994) 269:5680-6.

86. Grafer CM, Thomas R, Lambrakos L, Montoya I, White S, Halvorson LM. $\mathrm{GnRH}$ stimulates expression of PACAP in the pituitary gonadotropes via both the PKA and PKC signaling systems. Mol Endocrinol (2009) 23:1022-32. doi:10.1210/me.2008-0477

87. Kanasaki H, Mutiara S, Oride A, Purwana IN, Miyazaki K. Pulse frequency-dependent gonadotropin gene expression by adenylate cyclase-activating polypeptide 1 in perifused mouse pituitary gonadotroph LbetaT2 cells. Biol Reprod (2009) 81:465-72. doi:10.1095/biolreprod.108.074765

88. Braden TD, Conn PM. Activin-A stimulates the synthesis of gonadotropin-releasing hormone receptors. Endocrinology (1992) 130:2101-5. doi:10.1210/endo.130.4.1312442

89. Fernandez-Vazquez G, Kaiser UB, Albarracin CT, Chin WW. Transcriptional activation of the gonadotropin-releasing hormone receptor gene by activin A. Mol Endocrinol (1996) 10:356-66. doi:10.1210/mend.10.4. 8721981

90. Norwitz ER, Xu S, Jeong KH, Bedecarrats GY, Winebrenner LD, Chin WW, et al. Activin A augments GnRH-mediated transcriptional activation of the mouse GnRH receptor gene. Endocrinology (2002) 143:985-97. doi:10.1210/ endo.143.3.8663

91. Kumar TR, Agno J, Janovick JA, Conn PM, Matzuk MM. Regulation of FSHbeta and GnRH receptor gene expression in activin receptor II knockout male mice. Mol Cell Endocrinol (2003) 212:19-27. doi:10.1016/j. mce.2003.09.019
92. Fortin J, Ongaro L, Li Y, Tran S, Lamba P, Wang Y, et al. Minireview: activin signaling in gonadotropes: what does the FOX say... to the SMAD? Mol Endocrinol (2015) 29:963-77. doi:10.1210/me.2015-1004

93. Wang QF, Farnworth PG, Findlay JK, Burger HG. Effect of purified $31 \mathrm{~K}$ bovine inhibin on the specific binding of gonadotropin-releasing hormone to rat anterior pituitary cells in culture. Endocrinology (1988) 123:2161-6. doi:10.1210/endo-123-5-2161

94. Laws SC, Beggs MJ, Webster JC, Miller WL. Inhibin increases and progesterone decreases receptors for gonadotropin-releasing hormone in ovine pituitary culture. Endocrinology (1990) 127:373-80. doi:10.1210/endo127-1-373

95. Crowder ME, Nett TM. Pituitary content of gonadotropins and receptors for gonadotropin-releasing hormone $(\mathrm{GnRH})$ and hypothalamic content of GnRH during the periovulatory period of the ewe. Endocrinology (1984) 114:234-9. doi:10.1210/endo-114-1-234

96. Bauer-Dantoin AC, Weiss J, Jameson JL. Roles of estrogen, progesterone, and gonadotropin-releasing hormone $(\mathrm{GnRH})$ in the control of pituitary $\mathrm{GnRH}$ receptor gene expression at the time of the preovulatory gonadotropin surges. Endocrinology (1995) 136:1014-9. doi:10.1210/endo.136.3. 7867555

97. Cross JC, Rutter LM, Manns JG. Effects of progesterone and weaning on LH and FSH responses to naloxone in postpartum beef cows. Domest Anim Endocrinol (1987) 4:111-22. doi:10.1016/0739-7240(87)90005-1

98. Turzillo AM, Nett TM. Regulation of GnRH receptor gene expression in sheep and cattle. J Reprod Fertil Suppl (1999) 54:75-86.

99. Turzillo AM, Campion CE, Clay CM, Nett TM. Regulation of gonadotropin-releasing hormone $(\mathrm{GnRH})$ receptor messenger ribonucleic acid and GnRH receptors during the early preovulatory period in the ewe. Endocrinology (1994) 135:1353-8. doi:10.1210/endo.135.4.7925096

100. Nett TM, Turzillo AM, Baratta M, Rispoli LA. Pituitary effects of steroid hormones on secretion of follicle-stimulating hormone and luteinizing hormone. Domest Anim Endocrinol (2002) 23:33-42. doi:10.1016/S07397240(02)00143-1

101. Kirkpatrick BL, Esquivel E, Moss GE, Hamernik DL, Wise ME. Estradiol and gonadotropin-releasing hormone $(\mathrm{GnRH})$ interact to increase $\mathrm{GnRH}$ receptor expression in ovariectomized ewes after hypothalamic-pituitary disconnection. Endocrine (1998) 8:225-9. doi:10.1385/ENDO:8:3:225

102. Tobin VA, Canny BJ. Testosterone regulates gonadotropin-releasing hormone-induced calcium signals in male rat gonadotrophs. Endocrinology (1996) 137:1299-305. doi:10.1210/endo.137.4.8625903

103. Tobin VA, Millar RP, Canny BJ. Testosterone acts directly at the pituitary to regulate gonadotropin-releasing hormone-induced calcium signals in male rat gonadotropes. Endocrinology (1997) 138:3314-9. doi:10.1210/ endo.138.8.5334

104. Clarke IJ. Multifarious effects of estrogen on the pituitary gonadotrope with special emphasis on studies in the ovine species. Arch Physiol Biochem (2002) 110:62-73. doi:10.1076/apab.110.1.62.898

105. Adams BM, Sakurai H, Adams TE. Concentrations of gonadotropin-releasing hormone $(\mathrm{GnRH})$ receptor messenger ribonucleic acid in pituitary tissue of orchidectomized sheep: effect of estradiol and GnRH. Biol Reprod (1996) 54:407-12. doi:10.1095/biolreprod54.2.407

106. Gregg DW, Allen MC, Nett TM. Estradiol-induced increase in number of gonadotropin-releasing hormone receptors in cultured ovine pituitary cells. Biol Reprod (1990) 43:1032-6. doi:10.1095/biolreprod43.6.1032

107. Sealfon SC, Laws SC, Wu JC, Gillo B, Miller WL. Hormonal regulation of gonadotropin-releasing hormone receptors and messenger RNA activity in ovine pituitary culture. Mol Endocrinol (1990) 4:1980-7. doi:10.1210/ mend-4-12-1980

108. Cheon M, Park D, Park Y, Kam K, Park SD, Ryu K. Progesterone together with estrogen attenuates homologous upregulation of gonadotropin-releasing hormone receptor mRNA in primary cultured rat pituitary cells. Endocrine (2000) 13:379-84. doi:10.1385/ENDO:13:3:379

109. McArdle CA, Schomerus E, Groner I, Poch A. Estradiol regulates gonadotropin-releasing hormone receptor number, growth and inositol phosphate production in alpha T3-1 cells. Mol Cell Endocrinol (1992) 87:95-103. doi:10.1016/0303-7207(92)90237-Z

110. Weiss JM, Polack S, Treeck O, Diedrich K, Ortmann O. Regulation of GnRH I receptor gene expression by the GnRH agonist triptorelin, estradiol, and 
progesterone in the gonadotroph-derived cell line $\alpha$ T3-1. Endocrine (2006) 30:139-44. doi:10.1385/ENDO:30:1:139

111. Turgeon JL, Kimura Y, Waring DW, Mellon PL. Steroid and pulsatile gonadotropin-releasing hormone $(\mathrm{GnRH})$ regulation of luteinizing hormone and $\mathrm{GnRH}$ receptor in a novel gonadotrope cell line. Mol Endocrinol (1996) 10:439-50. doi:10.1210/mend.10.4.8721988

112. Davis TL, Whitesell JD, Cantlon JD, Clay CM, Nett TM. Does a nonclassical signaling mechanism underlie an increase of estradiol-mediated gonadotropin-releasing hormone receptor binding in ovine pituitary cells? Biol Reprod (2011) 85:770-8. doi:10.1095/biolreprod.111.091926

113. Geraghty AC, Kaufer D. Glucocorticoid regulation of reproduction. Adv Exp Med Biol (2015) 872:253-78. doi:10.1007/978-1-4939-2895-8_11

114. Whirledge S, Cidlowski JA. A role for glucocorticoids in stress-impaired reproduction: beyond the hypothalamus and pituitary. Endocrinology (2013) 154:4450-68. doi:10.1210/en.2013-1652

115. Daley CA, Sakurai H, Adams BM, Adams TE. Effect of stress-like concentrations of cortisol on gonadotroph function in orchidectomized sheep. Biol Reprod (1999) 60:158-63. doi:10.1095/biolreprod60.1.158

116. Adams TE, Sakurai H, Adams BM. Effect of stress-like concentrations of cortisol on estradiol-dependent expression of gonadotropin-releasing hormone receptor in orchidectomized sheep. Biol Reprod (1999) 60:164-8. doi:10.1095/biolreprod60.1.164

117. Tibolt RE, Childs GV. Cytochemical and cytophysiological studies of gonadotropin-releasing hormone $(\mathrm{GnRH})$ target cells in the male rat pituitary: differential effects of androgens and corticosterone on GnRH binding and gonadotropin release. Endocrinology (1985) 117:396-404. doi:10.1210/ endo-117-1-396

118. Suter DE, Schwartz NB, Ringstrom SJ. Dual role of glucocorticoids in regulation of pituitary content and secretion of gonadotropins. Am J Physiol (1988) 254:E595-600.

119. McGillivray SM, Thackray VG, Coss D, Mellon PL. Activin and glucocorticoids synergistically activate follicle-stimulating hormone beta-subunit gene expression in the immortalized LbetaT2 gonadotrope cell line. Endocrinology (2007) 148:762-73. doi:10.1210/en.2006-0952

120. Maya-Nunez G, Conn PM. Transcriptional regulation of the GnRH receptor gene by glucocorticoids. Mol Cell Endocrinol (2003) 200:89-98. doi:10.1016/ S0303-7207(02)00419-7

121. Kotitschke A, Sadie-Van Gijsen H, Avenant C, Fernandes S, Hapgood JP. Genomic and nongenomic cross talk between the gonadotropin-releasing hormone receptor and glucocorticoid receptor signaling pathways. Mol Endocrinol (2009) 23:1726-45. doi:10.1210/me.2008-0462

122. Yasin M, Dalkin AC, Haisenleder DJ, Kerrigan JR, MarshallJC. Gonadotropinreleasing hormone $(\mathrm{GnRH})$ pulse pattern regulates $\mathrm{GnRH}$ receptor gene expression: augmentation by estradiol. Endocrinology (1995) 136:1559-64. doi:10.1210/endo.136.4.7895666

123. Murase M, Uemura T, Gao M, Inada M, Funabashi T, Hirahara F. GnRH antagonist-induced down-regulation of the mRNA expression of pituitary receptors: comparisons with GnRH agonist effects. Endocr J (2005) 52:131-7. doi:10.1507/endocri.52.131

124. Hamernik DL, Clay CM, Turzillo A, Van Kirk EA, Moss GE. Estradiol increases amounts of messenger ribonucleic acid for gonadotropin-releasing hormone receptors in sheep. Biol Reprod (1995) 53:179-85. doi:10.1095/ biolreprod53.1.179

Conflict of Interest Statement: The authors declare that the research was conducted in the absence of any commercial or financial relationships that could be construed as a potential conflict of interest.

Copyright $\odot 2017$ Janjic, Stojilkovic and Bjelobaba. This is an open-access article distributed under the terms of the Creative Commons Attribution License (CC BY). The use, distribution or reproduction in other forums is permitted, provided the original author(s) or licensor are credited and that the original publication in this journal is cited, in accordance with accepted academic practice. No use, distribution or reproduction is permitted which does not comply with these terms. 